\title{
A multimodal analysis of conventional humorous structures on sensitive topics within rural communities in Romania
}

\author{
Violeta Rus \\ Transilvania University of Brașov \\ rusioanavioleta@yahoo.ro
}

\begin{abstract}
When it comes to humour, performing humorous structures means not only producing amusement, but also implies the ability of perceiving the comical, ludicrous or absurd in human life. In this paper, I consider humour as a way in which people in the rural community express themselves freely, without boundaries or constraints. Therefore, the interest of the present article is to identify and analyse sensitive humorous topics in Romanian rural communities. In conducting the study, the following steps were taken: I videotaped people from the Upper Valley of the river Mureș (selected with sociolinguistic criteria such as gender, age, occupation), I transcribed the audio-video records and I divided the data into thematic categories: jokes, traditional shouts and funeral songs or dirges with humorous structures. Starting from these methodological steps, I attempt to perform a multimodal analysis, which consists of analysing both the text and the audio-video record. In the first part of my research, the analysis of the text focuses on specific structures of conventional humour performed in jokes, traditional shouts and dirges by the main theories of humour: superiority, release and incongruity theories of humour. In analysing the audio-video stimuli, I dwell upon identifying the degree of influence of the psycho-sociolinguistic parameters (gender, occupation and context) on the performance of humour, concentrating on markers of humour such as intonation and visual cues. After analysing the humorous sensitive topics in Romanian rural communities through a multimodal perspective, my conclusion is that speakers combine linguistic and non-linguistic elements in order to make a text humorous.
\end{abstract}

Keywords: rural community, sensitive topics, humorous structures, multimodal, linguistic and non-linguistic.

\section{Introductory notes}

The main interest of the article is to analyse the sensitive topics in Romanian rural communities in order to identify which are the linguistic and non-linguistic elements that turn a text humorous and how speakers use opposite scripts to produce humour. To this end, I 
attempt to analyse the data via a multimodal perspective. Thus, in the first part of the article, I will analyse jokes, shouts and funeral songs or dirges by applying the main theories of humour (superiority, incongruity and release theories). Then I will focus on the non-linguistic markers of humour such as intonation, pitch of voice, imitation and visual cues in order to identify the degree to which psycho-sociolinguistic parameters affect the performance of humour.

More specifically, in this section I describe the Upper Valley of the Mures from a geographical and historical point of view; then, I present the methodological part of the research. In section 2, I present a short overview of the main theories of humor and then I will move on to analyse the data: jokes, shouts and funeral songs (section 3). In section 4, I discuss the influence of the psycho-sociolinguistic parameters on performing such humorous texts.

\subsection{Geographical remarks}

The river Mureș is the second longest river in Romania after the Danube. It springs from the Hășmașu Mountains and drains in the river Tisa, in Hungary. The Upper Valley of the river Mureș is located in the Central-Eastern area of Romania between the Izvoru Mureșului and Deda localities and represents the first part of the river Mureș's route. From the source to the exit of the Toplița-Deda Defile, the river Mureș crosses several villages: Izvoru Mureșului, Voșlobeni, Senetea, Suseni, Ciumani, Joseni, Borzont,, Remetea, Subcetate, Hodoșa, Sărmaș, Runc, Platonești, Gălăuțaș, Nuțeni, Moglănești, Călimănel, Vâgani, Ciobotani, Stânceni, Meștera, Neagra, Lunca Bradului, Sălard, Andreneasa, Răstolița, Iod, Borzia, Gălăoaia, Bistra Mureșului și Deda. The above-mentioned villages represent the geographical area from where I collected humorous data (jokes, shouts, funeral songs).

\subsection{Historical aspects}

Five of the thirty rural communities of the Upper Valley of the river Mureș (Senetea, Suseni, Ciumani, Joseni, Borzont, Remetea) are $98 \%$ populated by Hungarian people who live in Romania, the rest of the localities being populated more than $50 \%$ by Romanian people. It seems that this phenomenon has some historical routes, that is why in the Upper Valley of the river Mureș most of the Hungarian speakers who are Romanian citizens can be encountered. Simon de Keza writes in his chronicle (Dobreanu \& Dobreanu 1999: 9) about the settlement of the Hungarian people who arrived from the Pannonian Plain at the Romanian land early in the XIII century. In another document (Dobreanu \& Dobreanu 1999: 9), it has been found that in the XIV-XV centuries a large part of the rural communities from the Upper Valley of the Mureș belonged to the Hungarian Chair of Gheorgheni. Over the years, this historical phenomenon had influenced the Upper Valley of the river Mureș, in terms of costumes, values, language and culture. Another historical aspect, with a huge impact on the rural communities investigated is represented by the transhumance phenomenon of the Moldavian and Transylvanian people which took place at the end of the XVII century.

The two historical phenomena are very important for our study because, due to the cohabitation of Romanian people with Hungarian ones and the mixture between the aboriginal of the area and the sojourners, most of the topics of the humorous texts refer to the relationship created over the years between them.

\subsection{Methodology}

The main interest of the paper is to identify the linguistic and non-linguistic elements that turn a text humorous and how the speakers of the rural communities use the clash of the 
scripts to generate humour. The data selected includes audio-video recordings of humorous structures such as shouts (20), funeral songs (7) and jokes (50) performed by the people of the rural communities encountered on the Upper Valley of the river Mureș.

The language specific to the Upper Valley of the Mureș has been understudied and has not represented an area of interest for folklorists, ethnologists or anthropologists. Therefore, the only material I will analyse is that recorded by myself during 3 years of research. The joke number is higher than other type of texts because I had the opportunity to record my family, my friends or my neighbours due to the fact that I was born and raised in a village on the Upper Valley of the river Mureș (Sărmaș). The gathering of the other types of humorous texts that I am interested in (shouts, funeral songs or dirges) was a bit more difficult because I found only few older people who remembered parts of the texts since these are no longer performed at weddings or funeral/death watch as they were in the past.

Data transcription is made in Romanian and then translated into English. The transcription contains the essential phonetical and dialectal particularities that are important for the investigated area as well as the most relevant conventions: the stressed words/parts of the utterance, the falling/rising of the intonation or pitch, the imitation and that parts in which the performer is laughing and speaking at the same time or makes some gestures while he is talking ${ }^{1}$. All these conventions are useful in differentiating a humorous performance by a speaker from a rural community and the same text that can be found on the internet or told by another performer from a different geographical area. For the present study, I selected only those humorous structures that have sensitive topics such as sexuality, drinking and relationships between women and men.

In what follows, I will first present the main theories of humour and then I will analyse a series of jokes, shouts and funeral songs/dirges starting from superiority, release and incongruity theories.

\section{Humour: A short overview of the main theories}

Humour is a concept that is difficult to define accurately for the simple reason that throughout history it has elicited the interest of scholars from various domains, such as psychology, anthropology, sociology and, last but not least, linguistics. However, a broader definition of humour would include the intention or ability to utter sentences that entail a specific reaction: a type of emotion or an expression through laughter (Zafiu 2007: 497). Humour entails unexpected, ridiculous resolutions and can generate hilarity. Pragmatically, "humour represents the intention and/or ability to utter sentences that generate a certain characteristic (a type of emotion/expression through laughter)" (Zafiu 2007: 497). It can have a benevolent nature that enables the initiation of a relationship, or it can be caustic and destructive.

Humour has two main prerequisites: the intention to produce an utterance capable of generating laughter and the effect that the former has. In the fortunate case of a successful humorous act, the two conditions are associated. There are situations in which the lack of response to humour can be labelled as "forced humour". The existence of a humorous effect without the intention of performing a humorous act is called "involuntary humour" (Zafiu 2007: 497).

The existing theories on humour are generally deemed complementary. There are certain fine distinctions that divide the theories into the following categories: linguistic, cognitive and non-linguistic theories that establish the anthropological and psychological causes. All three major theories are deemed relevant to our study, namely the theories of superiority, of relief and of incongruity. 
The first theory that is of interest to the present study is the one regarding the concept of superiority. Ludovici (1932) put forward the idea that all theories centred on humour could be classified in consonance with the views of philosopher Thomas Hobbes. As stated by Hobbes (1651 [1982]), when we acknowledge humour, we burst into laughter because we look down on the stupidity, failure, cultural or moral flaws of the interlocutor, towards whom we feel "superior", because in that particular moment, we are not the ones experiencing bad luck. In these terms, feeling superior stands for "feeling good about oneself", "obtaining what one wants", "winning".

Gruner (1997) develops Hobbes' ideas on humour and devises "the theory of superiority". He follows the same line according to which laughing means winning, because it entails obtaining a pleasant and desired matter. Moreover, he argues that each humorous situation involves both a winner and a loser. Thus, the "winner" is not only the author of the joke, but also its addressee, as along as the "loser" is a third party that the joke is about.

Another theory found at the core of our analysis is the relief theory of humour. Its main representative is Freud (1905 [1974]) who states that humour mainly underlines the decrease of the arousal, meaning that stimuli-triggered laughter is prompted by the necessity to relieve the inner tension (usually associated with sexuality, aggressiveness or death) that the individual suppresses. Thus, there are differences regarding the sources of laughter, as it reflects the intensity of the emotions (suppressed or inhibited) in connection with the relevant stimuli of a given comical situation. What is more, according to Freud's theory, humour stands for negative feelings, thus, instead of pain, one feels pleasure which derives from the economy of an emotional burden.

The theory of incongruity has its roots in the philosophy of Kant (1790 [1911]) and Schopenhauer (1818/1844 [1907]) and it is one of the most important theories for the study of humour. According to both philosophers, laughter occurs when the incongruity between a concept and its correspondent in reality is suddenly perceived. In a similar vein, Koestler (1964) states that humour emerges from the simultaneous intersection of two distinctive ways of thinking regarding the same information or experience.

The most eloquent example is the overlap between two semantic structures which leads us to one of the most prominent incongruity theories on humour: the Semantic Script Theory of Humour (SSTH). This theory was proposed by Raskin (1985) and suggests a script-based linguistic perspective. We can identify humour in oral or written communication when "the text is fully compatible with two scripts and these two scripts are in contrast with each other, for example: sexual / non-sexual, good / evil or real / unreal" (Raskin 1985: 99). According to the theory, a joke becomes ambiguous only at its end, also named the punch line, when the transition from one script to another is allowed. This is the only moment when the receptor of the joke becomes aware that from its very onset, the joke allows two interpretations. Attardo developed Raskin's theory into the General Theory of Verbal Humour (GTVH; Attardo \& Raskin 1991), in order to account for any type of humorous text, as SSTH is strictly semantic and referring to jokes. In their theories, the two scholars converge in that a text can be considered humorous when it complies with two criteria: the text is compatible with two different scripts and the two scripts are opposing.

\section{The analysis of the data}

\subsection{Jokes with religious substratum and sensitive topics}

Conventional humorous acts refer to those jokes, shouts, funeral songs or dirges that are not spontaneously generated but follow a predetermined, fixed pattern. When interpreting 
conventional humour, a three-component model that includes the aforementioned theories can be employed. These are: the cognitive-intellectual mechanism that deals with incongruities, contrast and surprises, as well as the involved values and emotional associations, which require emotional responses and determine the opposition between the social and individual levels. Suls (1972: 83) considers that, when a joke is performed, pieces of knowledge are reactivated thus involving a series of expectations that come in contradiction with the real meaning of that joke. The interference of those 3 levels is most easily noticeable in jokes.

The first example analysed here is a joke performed by a 59-year old informant. In this case, we observe that two contrasting cognitive scripts overlap and are dissociated, namely the script in which the woman goes to the priest to ask him to read her the molifta, that is, the prayer which the priest reads to a woman 40 days after giving birth, but this prayer is substituted by the one alluding to sexuality:

(1) Măria \# o făcut un copcil\#\#. nó șî 1era cu vremurile alea cîn nu purta bud"igăi sau cum ai zîs în ciuitura aia $\downarrow$ șt"i? așă ǐera vremurile $\downarrow$ nó! șî \# s-o dus cu băiętu' la moliftă $\downarrow$ la părint"ele. $<_{\mathbf{R}}$ da era faină Măria, n-avęi treabă cu Măria>. șî \# popa i-o zîs să puie acol cu copĉilu-n genunĉ șî să:: șî să: să zîcă după el \# rugăŝiuńile. șî nó \# î:: o zîs popa ŝe-o trebuit să zîcă d"in cart"e $\downarrow$ ș-o zîs să să rid"ŝe sus. <î ię cîn s-o rid"icat $\downarrow$ ș-o prins roĉa sus $\downarrow$ cu copĉil cu tătu'> ș-o rămas cu::: d"iscopirită. ș-amu cum o zîs popa că să zîcă ŝe zî̂̂e el $\downarrow$ cîn o văzut popa zîŝe $<_{\text {IM }}$ dă Mărie ia žos! > da ię după popa $<_{\text {IM }}$ dă mărie ia žos!

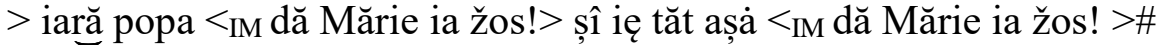

O văus că nu-nțălęĝe $\downarrow$ zîse: ă:: $<_{\mathrm{IM}}<_{\text {MARC }}$ dă Mărie ia žos $\downarrow$ că să vęd"e spurcăŝiuńa șî nu pot zîŝe rugăsiiuńea! >> ((toată lumea rîde)).

Maria gave birth to a child. And there were those times when she didn't wear knickers or like you've said in that holler. But those were the times! And she went with her son to be read the molifta by the priest. Oh, but Maria was really nice, this can't be denied. And the priest told her to kneel with the baby there, and repeat after him the prayers. And the priest said what he had to from a book, and he told her to stand up. And when she stood up, she caught and lifted her dress in the upper part, together with her child, and she remained with her... uncovered. And then as the priest said that she had to repeat after him. When he saw that, the priest said: "Pull down your skirt, Maria!" She repeated after the priest: "Pull down your skirt, Maria!" And the priest continued: "Pull down your skirt, Maria!" and she repeated after him: "Pull down your skirt, Maria!" When he saw that she didn't understand, he said: "Pull down your skirt, Maria, 'cause your privates are uncovered and I can't say the prayer!'” ((everybody is laughing)).

We notice the fact that the incongruity derived, first of all, from the contradiction regarding the setting and moment in which the two characters of the joke are set. This incongruity is also emphasised by the discrepancy between the social position of the priest and the human weaknesses he proves in an unsuitable context. The cognitive contrast is intensified by the social and religious values implied, in order to stress the humorous effect of the text. Therefore, the religious command of not sinning in action or thought is violated by the disturbance of the priest who no longer says the prayers because he is distracted by the private parts of the woman.

Humour is here performed through different types of strategies. Given that it was a joke inserted within a conversation, the informer referred to topics that had been previously discussed. He prepares the receiver regarding the climax of the joke ("she didn't wear knickers"), and underlines: "Oh, but Maria was really nice, this can't be denied about 
Maria', justifying even from the very beginning the priest's attitude. In Freud's (1905 [1974]) terms, this is the point in which the arousal increases, and from the psychosociological point of view, given the fact that the informant that performs the humorous act is male, the observations he makes from the very beginning are justified by means of the creation of a possibility to legitimise the attitude of the priest.

From the linguistic point of view, the main method that triggers humour in this joke is the wordplay with an erotic connotation: the Romanian word spurcăciune 'a woman's privates' rhymes with rugăciune 'prayer'. There are two reasons that made the speaker use the word spurcăciunea '(lit.) filth' instead of the word normally used to describe that part of the body: on the one hand, it is indecent to mention the common word because of the role the male character had in that situation; on the other hand, from an anthropological point of view, it is a suitable euphemism, as the female genitalia represent a filthy temptation (spurcat) according to customary belief.

The second joke is introduced within a conversation and it unfolds based on a script similar to the one presented above:

(2) Informatorul 1: Da aia \# ous că era una Năstăsîia, șt"'ii?

Informatorul 2: Da auzảm d"e ǐę:

Informatorul 1: Apăi faină era ş-apăi = =Informatorul 2: Așá ca $\perp$

Informatorul 1: $\mathrm{Da}, \mathrm{ca}=$

= Informatorul 2: Ca drujba

Informatorul 1: Ș-apăi s-o băgat $\perp<\mathbf{R}$ întătd"auna să expuńę în faţă-n bisęrică $\downarrow$ acol $\downarrow$ PUȚULITĂ $\downarrow$ pusă la punct $\downarrow$ n-avęi treabă cu ię $\downarrow$ înțălež? > ei $\uparrow$ mă frat"e $\downarrow<$ I șî cantoru să grăbgę und"eva-n dumińica aia că trăbę să margă NAPARAT trăbuię să margă und"eva. POPA $\uparrow$ frat"e $\downarrow$ trăžę d"e t"imp. să uita $\downarrow$ me zîsęe:: $<_{\text {IM }}$ miluięșt"e dómńe poporul tău șî bińecuvînt"ază moșt"eńir'a ta! > ((arată cum face preotul când spune rugaciunea)) șî să uita la ię \# c-așȧ-i zîsę $\downarrow$ NASTA $\downarrow$ NASTA $\downarrow$ că era frumósă: $=$

=Anchetatorul: Așá o alinta =

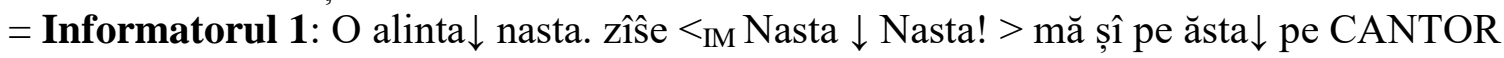

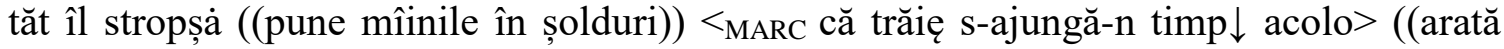
spre ceasul de la mînă)). iară mă-ieșá popa acolo $\downarrow$ me zîsę ŝe zîsę cu căd"ęlnița ((arată

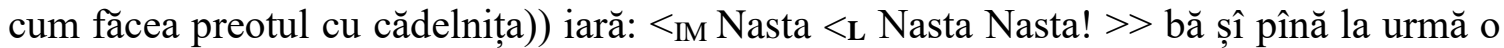
văzut că ăsta trăbę să ${ }_{\text {MARC }}$ PLĘŜE d"e la bisęrică> , că trăbę s-ažungă-n t"imp. odată so-nervat $\downarrow$ faŝe $<_{\text {IM }}<_{1}$ n-a sta pe dracu părint"e $<_{\mathbf{R}}$ dacă la cantor o stat la popa n-a sta? >>> @ hai că mă duc, că am tr'abă. > ((toată lumea rîde))

Informatorul 2: <@ La popa n-a sta? >

Informatorul 1: <@ La popa n-a sta?>

Informatorul 2: <@ La popa n-a sta?>

Informant 1: Yes, he said that there was a woman called Năstăsîia, you know?

Informant 2: Yes, I've heard of her

Informant 1: And she was very nice and then

Informant 2: As the ....

Informant 1: Yes, as that ....

Informant 2: As the chainsaw

Informant 1: And then she went in front, she's always displaying herself in the front row during the service, just right there, exposing herself, so well dressed, that there was nothing you could criticise, do you get it? And, brother, that Sunday, the cantor was in a rush because he had to get somewhere without fail, he had to get there. The priest, 
brother, he was playing for a while. He was looking, and then he was saying: "Oh Lord/God, have mercy upon Your people and bless Your heritage!' and he was looking at her again, he called her "Nasta, Nasta", "cause she was so beautiful.

Interviewer: This was her pet name

Informant 1: He affectionately called her Nasta. He said: "Nasta, Nasta!'. As for the cantor, the priest was giving him the rough side of his tongue "cause he had to be there on time. And the priest got out there again, he was saying what he had to say, he told himself, then again ...." Nasta, Nasta, Nasta!" and in the end he noticed that the cantor had to leave the church 'cause he had to arrive on time. He, the cantor, suddenly got angry, and said: "Damn it, father, if she went all the way with the cantor, wouldn't she go all the way with the priest? I have to go, I have work to do".

Informant 2: Wouldn't she go all the way with the priest?

Informant 1: Wouldn't she go all the way with the priest?

Informant 2: Wouldn't she go all the way with the priest?

In this case, the joke does not have a fixed structure as in the first example. We can notice that the interventions by informant 2 and by the interviewer increase the humorous effect of the text. From the point of view of humour theory, we notice a similarity between the two examples, regarding the context, the characters of the text (the priest and a certain woman), and the sexual allusion that appears at a certain moment. Thus, in accordance with the incongruity theory, there are two contrasting scripts that overlap, and there are also elements which bring the priest and the woman into disrepute, as the first one feels attracted to a parishioner during the religious service, while the other seems to be a frivolous woman. The humorous effect is produced by means of a pun based on the Romanian proper hypocoristic noun Nasta which is pronounced the same as the informal negative form of the verb sta 'to stay', that it, $n$ - $a$ sta 'wouldn't stay', which in Romanian is an informal way of saying that a woman would not accept to go to bed with someone.

Rendered by the same speaker, the jokes are also performed in the same context. Based on the entire corpus, I can say that the proposed humorous scripts are strongly influenced by the social status of the informant (parish clerk). Therefore, we notice that in both humorous situations, the context and the speakers are the same, and this can be explained through the nature of the occupation that the narrator had in the past, namely a cantor 'parish clerk' at the church.

\subsection{Ethnic jokes with sexual connotation}

In the following examples, the friendship between two men of different ethnic groups is displayed. The focus is on the mercy of the Romanian who hosts a Hungarian runaway who eventually betrays his Romanian friend.

(3) Sau tot așă $\downarrow$ era tot așă prięt"iń iǐ tot ungur' așả $\downarrow$ un ungur șî c-un romîn. ș-apăi meržęu iĭ la un $<_{L}$ pahar d"e vin> așȧ seara nu șt"u ŝe șî ă:: \# ăsta ă:: unguru' grăię cam stîlci::t romînéșțt"e $\downarrow$ șt"ii? șî ăsta romînu' tăt îl corecta. $<_{\mathbf{R}}$ Nó $\downarrow$ după ŝe-o băut î̀ $\downarrow$ acolo cît o

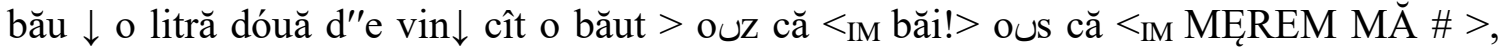
ouz că $<_{\text {IM }}$ la fumeile noștri \# > , ous că $<_{\text {IM }}$ așả le iubim pîn la Dumńezo $>$.

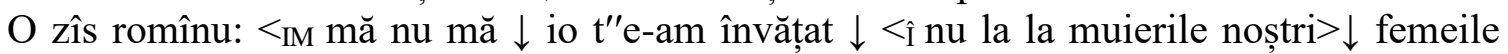
noștri, la femeile nóstre!> \# bun \# A dóua zî iară să-ntîlńesc la žin. \# MÁ șî zî̀̂e $<_{\text {IM }}$

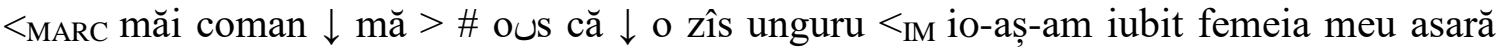
d"e:: \# > ous că $<_{\text {IM }}$ t"e-o trăsńit!> o zîs $<_{\text {IM }}<$ î mă $\downarrow$ ț-am zîs $\downarrow$ nu a mńeu $\downarrow$ a a mę. $>><_{I M}$ o:::> o zîs că $<_{\text {IM }}$ pe-a ta alaltăsară! $<@$ pe-a ta alaltăsară, nu-ț faŝe tu probleme. $>>(($ toată lumea rîde)). 
So, there were two friends. A Hungarian and a Romanian. And then they went to drink some wine, in the evening, and this man, err, the Hungarian spoke Romanian badly, you know? And this Romanian guy kept correcting him. And, after they drank together, for some time, one or two litres of wine or whatever they drank, they said: "Hey!" he said "let's go....." they said "to our women..." they said that "we love them as much as we love God". The Romanian said: "Hey, no, I taught you, not at our women, our women, at our women!", Good. The second day they met to drink again. And he said: "Hey, old fellow, you...", they said that the Hungarian said: "I so loved, our woman last night eh..." He said: "Hey, I told you, it's not correct to say our woman, you should say my woman". He said that: "I loved yours in the evening of the day before yesterday!", "I loved yours in the evening of the day before yesterday, don't worry" ((everybody is laughing)).

In example (3), we notice that there are not only elements specific to ethnic humour, but also a sexual reference. Living in a community in which over $80 \%$ of the population is Hungarian, the speaker makes a joke that portrays the relationship between Romanians and Hungarians. From the content of this joke, not only more information regarding the life of the Romanians and Hungarians together can be extracted, but also the fact that, being surrounded by Romanian people, the Hungarian man borrows some particularities from the dialect spoken in that specific area: woman (in Romanian standard language femeie, in the spoken dialect fumeie); like this (aşă instead of the standard așa), last night (asară instead of the standard word aseară, where the diphthong ea becomes $a$, which is a very common phenomenon in the Transylvanian dialect), don't worry (nu-țfase tu probleme - the word fase instead of face contains the consonant $\hat{s}$, a specific phonetic particularity of the spoken dialect).

Furthermore, the applicability of the superiority theory is evident in this case, if we take into account the attitude of the Romanian, who is always correcting the Hungarian. In Gruner's (1997: 32) terms, not only the one who tells the joke, but also the Romanian are in the position "of the winner", while the Hungarian is "the loser". However, at the end of the joke, we notice that roles change, thus the Hungarian becomes "the winner" because he is the one who laughs at the end.

Among the strategies through which the joke is performed, the literal interpretation is important. This one is favoured in the final joke and thus creates a surprise. In this case, the Romanian keeps on correcting his Hungarian friend, but this time, the latter, by literally using the words that the Romanian guy had uttered: "it's not correct to say ' $m y$ woman', you should say "my woman"". The Hungarian answers: "yours in the evening of the day before yesterday!', suggesting the fact that all the Romanian's interventions about speaking correctly intensify the final point, because the Hungarian man seems to know the correct form of the pronoun, but he is unwilling to use it.

(4) Vińę u::n $\perp$ în timpul războiului \# \# un refugiat \# \# o fost fužit d"e pe front ş-o lót-o pribeag prin România pe-acol așȧ \# \# șîntr-n-o sar-o ajuns uńeva șî \# \# \# \# na \# $<_{\mathbf{R}}$ doi t"ińer' căsătoriț> ș-o zîs că:: ă:: le-o cerut ca să pótă dormi. Ș-o zîs $\uparrow$ așt"ia că $<_{\mathrm{IM}}$ mă omu' lu' Dumńezo sfîntu $\downarrow$ noi n-avem numa un pat> că era vremurile alea așă gręle\# $<_{\mathrm{IM}}$ avem numa un pat șî nu să pót"e $\downarrow$ nu să pót"e $\downarrow$ zî̂e> . da:: ăsta era ungur fužit $\downarrow$ nu era romîn $\downarrow$ era ungur. Șî:: \# nó să să culŝe acolo i-o dat ŝeva d"e mîncare șî pînă la urmă

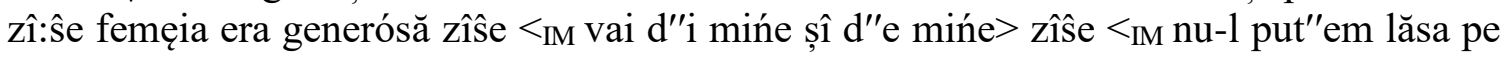
om>. Că atunŝ era nu era pod"it pe žos $\downarrow$ era căs cu lut cum era vremurile alea $<_{\text {IM lasă să }}$ să culŝe aiŝa lîngă noi > zî̂িe \# $<_{\text {IM }}$ io mă culc la mńijloc $\downarrow$ tu la maržińe șî unguru' la peręt"e. Pist"e nópt"e unguru $\downarrow$ ungur \# soldat acolo $\downarrow$ s-o dat la dómna $\downarrow$ da la un momenudat cîn era treaba-n toi să trăzęșt"e bărbatu-so. O zîs că: < IM tu $\downarrow$ mńie mi să pare 
că faŝ dragost"e cu unguru'!>/ $<_{\text {IM }}$ așă mi să pare șî mńie $>/<_{\text {IM }}$ da d"i ŝe nu zîs ŝeva?>/ <IM păi dacă nu șt"iu unguręșt"e ŝe să zîc?>

There came a ..... During war, a refugee, he was a runaway from the front, and he wandered through Romania, just like that. And one evening he arrived somewhere and .... So, two newly-weds said that he asked them to allow him to sleep in their house. And they said: "Hey, my good man, we only have one bed", because those times were very difficult. "We only have one bed, and it's not possible", he said. But he was a Hungarian runaway, he wasn't Romanian, he was Hungarian. And even if he couldn't/wouldn't sleep there, they gave him something to eat, and in the end the woman said, she was generous, she said: "Oh dear, she said, we cannot leave the man like this". Because then, there wasn't decking on the ground, the floor was made of clay, those were the times, hey, you can sleep here beside us, she said, I'll sleep in the middle, you'll sleep at the edge, and the Hungarian next to the wall. During the night the Hungarian, like Hungarians, like a soldier, he made a pass at the lady, and at a certain moment, when they were in full swing, her husband woke up. He said: "You, it seems to me that you are making love to the Hungarian!'. "It seems to me that you are right". "But why didn't you say anything?" "Err, if I don't know Hungarian, what could I say?",

In the fourth example, two pragmatic and rhetoric techniques are used to create humour: anticipation and pseudo-argumentation. The Romanian's wife anticipates what is going to happen from the very moment when she suggests to her husband that the refugee should sleep in bed with them. The second strategy used within the humorous structure presented above is the pseudo-argumentation, which is actually the way in which the wife explains the unjustifiable event: "Err, if I don't know Hungarian, what could I say?" Incongruity appears only at the end of the joke, when the audience expects an answer like: "I couldn't because...!" or "He didn't let me!", but receives a total different one: "Err, if I don't know Hungarian, what could I say?"

At the same time, in the two examples, the theory of superiority is very well pointed out. In both cases, although being cheated on, the Romanian is superior to the Hungarian from a moral point of view. The Romanian is generous, receives the Hungarian and offers him a place to sleep, but the latter betrays his trust. Therefore, according to the ideas postulated by Hobbes (1651 [1982]), by means of the moral flaws of the Hungarian, the Romanian becomes immediately superior, and the final joke creates amusement no matter if its cause is stupidity, failure, cultural flaws, immorality, or if one of the characters is in an embarrassing position.

\subsection{Shouts and funeral songs on sensitive topics}

\subsubsection{Shouts}

The following two examples are taken from The Hen's Shout' which is one of the songs and shouts specific to the wedding parties held in the Upper Valley of the Muress. It includes allusions to sensitive topics. The narrative script and the fact that the sender prepares the audience for direct interaction are the elements that makes the structure of text particularly interesting:

(5) <î ASAră pe însărat/ Io DUpă găin-am dat/ Șî FUžin după găină/ Am SĂrit pist"-un părău/ Șî mi-am RUPT on bud"igău. > 
Last night at dusk/I went to get the chicken /and while running after the chicken/I jumped over a stream/and I broke it in the knickers.

Unlike jokes, the shouts are humorous structures that have a specific referent. Therefore, the sender addresses directly the target receiver; in this case, the shouter (the person who shouts) was speaking to the godfather. However, at the wedding, which was the occasion when the following holler is performed, the receiver was usually a collective one and it was represented by the guests:

(6) <îNĂnaȘUle d"e nu crez,/ RăD"Ică roĉa șî vez/ HOP $\downarrow$ găină $\downarrow$ HOP! >

Godfather if you don't believe it, Peep under my dress Hop, hen, hop!

This is an affiliative type of humour (Martin et al. 2003) because its role is to amuse, to create cohesion in the group, a complicity of the type "to laugh with...". In this case, the goal is to tell jokes about things that might be found funny by everyone. In such cases, humour brings people together and its aim is to create a sense of happiness, well-being and fellowship. Zafiu (2007: 497) classifies humour into humour of inclusion and humour of exclusion, mentioning that sometimes these types can function simultaneously. In the present case, if we take into account the sexual allusion which the female sender addresses to the godfather, an allusion which is perceived in a positive way, we can talk about contextually dependent, interactional, social humour of inclusion.

In example (7) the sender creates a script in which 'the main character' is the same target referent — the godfather, without addressing him directly:

(7) <î PAre-m BIńe d'i ŝe-m pa:re::/ C-am ŜEluit nunu' ma: re::/ IO i-am <z DAT-O că-i puicuță/ ȘÎ el II cucoș cu p..ă/ HOP găină HOP! > ((râde))

I am glad, I seem to be/That I helped the godfather/I gave it to him because it's a chick/and he is a rooster with cock/ Hop hen hop! ((laughing))

From a semantic point of view, sequence (7) illustrates an incongruity based on a juxtaposition. The text contains some elements, which have both a literal and a hidden meaning, that overlap: first of all, because the song is called The Hen's Holler, the word chick can have its main meaning ('female baby chicken') or it can be a euphemism for the female genitals. As a matter of fact, the reaction to this type of humour can be laughter only when the word chick is associated with the second meaning.

Another example that belongs to the category of hollers alluding to sexuality is the following:

(8) <î Tu MŃIreasă, draga mę::/ MÂIńe sară ŝe-i vid"ę::/ Dóuă RÓt"e de motor/ Ș-un șofęr cu capu' gol. >

You bride, my dear/tomorrow evening you'll see/two wheels of an engine/and a driver without a cap.

When we analyse this humorous structure, we notice that it has a target referent, that is, the bride; the adverb of time tomorrow suggests the wedding night; and the last two lyrics represent a clear allusion to the male genitalia. The mix of registers is evident in this example, and the comic derives precisely from the association between the archaic form wheels and the noun testicles or the driver without a cap and the male genital organ. I believe 
that the expressions used by the speaker in order to suggest that the sentence is about the male genital organ, becomes relevant, otherwise the allusion would not be perceived, and the linguistic structure would not produce humour.

\subsubsection{The lamentations or lyrics sung at funerals (funeral songs)}

Although lamentation songs constitute folk ritual poetry that accompany funerary manifestations, (i.e. songs for the dead), some modifications that produce laughter can be made. In this case, the humorous effect is increased by the presence of affectivity, by some values and deep feelings that are mentioned in the script that the informant presents before the actual performance of the lamentation song.

(9) Me d'imult cîn murę:: \#\# murę:: bărbatu' la femęie șî murę șî plînžę. Ș-amu-l cema $\uparrow$ Constantin. Ș-o mărs la sicriu \#\#\# ș-o zîs $<_{\text {IM }}$ vai $\downarrow$ CONSTANTIŃE $\downarrow$ CONSTANTIŃE/ Rău îmupare după t"ińe::: ((imită plânsul femeii)/Dară tăt mai rău îmupare/ D"e ŝe ai tuntre pĉiŝ́óre > ((imită din nou plânsul femeii)).

Long time ago, when he died ... the woman's husband died and he died and she cried. And his name was Constantin. And she went to the coffin ..... and said: "Oh dear, Constantin, Constantin/ I feel sorry that you've passed away ((imitates the woman's cry))/ But I am even more sorry that what you have between your legs is also gone" ((he/she imitates again the woman's cry)).

Before the actual performance of the lamentation song, the informant explains the situation in which it was performed: a man called Constantin died and his wife composed a lamentation song for him. This example suggests a form of black humour, in which we can immediately grasp the juxtaposition of two different scripts: the tragic script in which a certain man died and the script which alludes to the male genital organ. At the same time, humour is enhanced by the performer's intonation which creates a comic and resounding effect. The stylised intonation, specific to the sung ritual poetry, offers a special melodic contour, called vocative intonation (Ladd 1978), that is, a "spoken song" which - through the melodic line specific to this folk species - is not appropriate for the conveyed message. As a matter of fact, the process through which the informant assumes the role of the woman who mourns her husband contributes to the enhancement of the humorous effect. We notice that the informant imitates the woman's cry and at the same time uses gestures such as pressing the hands together against the chest, changing the intonation pattern by elongating the vowels, interrupting the voice, as if she would choke from sobbing.

(10)Informatorul 3: O fost așă:: on bărbat \#\# o fost așă tare bun. cu tăt"e fimeile șî iubăreț. <MARC avę femei mult"e, mult"e> mă-nțălęgeț? nó bărbatu' $\uparrow$ o muri::t \# dac-o murit bărbatu' $\downarrow$ tăt"e femeile șî drăguțăle lui $\downarrow$ tăte s-o s-o boŝit $\downarrow$ tăt"e o mărs pe lângă el la scriu <R ș-așă ș-așă șî pe d"incóŝe șî pe d"incolo>. sara la priveci $\uparrow$ o fost asta. ș-o zîs că $\perp$ ascultă! ă:: tăt"e $<_{\mathbf{L}}$ 1-o plîns șî 1-o boŝit $>$ ș-o plîns tăt"e $\downarrow<_{\mathbf{R}}$ prima sară $>_{\text {. }}<_{\mathbf{L}}$ 1-o boŝit șî tăt"e $>\perp$ femęi-sa sta așă la capu' lui şî plînžę numa șî nu zî̂ęe mńic că nu șt"ię ŝe să me zîcă că d"e năcaz că $\perp$ dacă $<$ R mîndrele ŝęlea care le-o avut $\downarrow$ drăguțăle $\downarrow$ îl plînžę .

Informatorul 4: apăi în sęeia sară:: = =Informatorul 3: nu! nu sară $\downarrow$ că zuŭa [cîn 1-o mormîntat!

Informatorul 4: [<î sara> sara sęelaltă la priveci $\downarrow$ apăi n-o boŝit cîn o fost popa $\downarrow$ nu ŝi próstă! ((toatălumea rîde)) 
Informatorul 3: În sęia sară la prive:ci $\perp$ da nu că tăt zîua o fost\#\# $<_{\text {MARC }}$ o vinit POPA d"e 1-o pus în săcriu> șî \# nó\# să siie:: ca lumea. Ș-o prins a plînže femęi-sa $\uparrow$

<IM Dražile męle muieri/ Care-aţi fost la boŝit ie:::ri/ Șî m-aț povist"it în sa:t/ Că n-am plîns pe-al meu bărba:::t/ Vai $\downarrow$ nu 1-am plîns că n-am putut/ Că pe tăt"e v-o futut./ Da de-amu l-oi plînže-ntruna/ Mîndrele să-i mînŝe pula>.

Informant 3: He was such a man, he was so good with all the women and loving, he had many women, a lot, do you understand me? Err, the husband died .... If the husband died, all the women and all his sweethearts, all of them cried, all of them walked by the side of his coffin and they worried as if they were on the rack in the evening at the death watch it was like that. And he said that, listen! All of them cried for him, and all of them mourned him the first evening. And all of them cried .... His wife was sitting like this next to him, and she cried all the time and she didn't say anything because she didn't know what to say, she was so upset because of those lovers that he had, the sweethearts who mourned him.

Informant 4: Then, next evening..

Informant 3: No! Not in the evening, but during the day, when he was buried!

Informant 4: In the evening, the other evening at the death watch... err... they didn't mourn him when the priest was there, don't be stupid! ((everybody is laughing))

Informant 3: Next evening at the death watch. No, it was actually during the day... The priest came and he put him in the coffin, as they do. And his wife started to cry: "My dear women/who came to mourn yesterday/and gossiped about me around the village/that I didn't mourn my own husband/oh dear, I didn't mourn him because I couldn't/'cause he fucked all of you/. But from now on I will mourn him all the time/may the lovers eat his dick."

The script of this text is a simple one: a man loved by the women in a village dies, and at the death watch, all the women mourn him, except for his wife. The last evening, she starts mourning as well, but the message is addressed to the other mourners, and not to the dead person, as it would be expected. Besides the humorous effect, produced among the audience in a "forced" way by the content of the message, a dose of sarcasm can be sensed, which is deliberately performed and addressed to the target referents, namely "the lovers"'. From a Freudian perspective (Freud, 1905 [1974]), the sequence is part of the humorous structures, because it fulfils a very important condition: the liberation from censorship, not only that of sexual nature, but also that of frustration. The same author argues that a joke can be tendentious or innocent, but the one that triggers laughter is the malicious one.

The humour of lamentation is based on the clash of two incongruous scripts: one script represents the custom of mourning a dead man and the opposite one highlights the conflict between the wife and the lovers (that are crying more than his wife does) which takes place in an inappropriate place, at the death watch.

The third example from the category of the lamentation songs has a complex as well as interesting structure:

(11)Bucură-t"e cintirime/ Că frumósă flóre-ț vinee::: / Ah $\downarrow$ vai $\uparrow$ mamă dragă $\downarrow$ scumpa mę copcilă $\downarrow$ ((imită plînsul mamei și duce mîinile la piept))/ Vai $\uparrow$ bucură-t"e $<_{\text {MARC gaură }}$ ńagră $>$ / Că frumósă flóre-ț BAGĂ::/ Vai $\uparrow$ scumpă $\downarrow$ dragă $\downarrow$ copcila mę scumpă: /Vai $\uparrow$ vai $\uparrow \mathrm{PACRINT}{ }^{\prime} \mathrm{E} \downarrow \mathrm{PĂRINT}{ }^{\prime} E \mathrm{E}-\mathrm{O}$ BĂGA/ Că-i afundă GAURA::/ Vai $\uparrow$ vai $\uparrow$ părint"e dragă/ vai $\uparrow$ i-afundă șîn-ntuńecată/ Șî n-o poț scót"e SCULATĂ/ Părint"e dragă n-o băga:: / Ah $\downarrow$ ah $\downarrow$ ha $\uparrow$ vai MĂRIE dragă/ D"i ŝe-ai murit tu dragu' mamii? / Da d"i ŝe-ai murit tu $\downarrow$ ha? / N-ai avut tu ŝe mînca?/ ah $\downarrow$ hă $\uparrow$ hă. 
Be happy cemetery/That a beautiful flower you will receive/Oh, dear mother, my dear child/Oh dear, be happy black hole/That such a beautiful flower you will be inserted in/Oh, dear child of mine/Oh dear priest, priest do not insert it/'cause the hole is deep/Oh my dear priest/Oh dear, it's deep and it's darkened/And you cannot take it out alive/firm/ My dear priest do not insert it/ Oh, oh, oh, dear Mary/Why did you die my dear?/But why did you die my dear?/Didn't you have enough to eat?/Oh, oh, oh...

The mechanism of incongruity construction is evident through the juxtaposition of two completely different scripts. The depicted moment is a tragic one: a young girl dies and her mother mourns her before she is buried. The construction of the lyrics requires two models of interpretation: a literal one that refers directly to the unhappy event, and another that alludes to the sexual act. The overlapping of the two scripts - the moment before being put in the grave and the erotic act-represents an absurd situation, especially because all the replies are uttered by the mother of the dead girl. The key words or phrases that refer to the erotic theme are: black hole; he will insert it in you, priest do not insert it/that the hole is dark, alivelfirm. These are often used with a pejorative connotation, hence the inappropriate association with the context in which they are performed. Eventually, as the speaker is performing the text, we become even more aware of the discrepancy between the proposed scripts, its structure suggesting a double meaning, that may mislead the audience or that can be decoded only by a certain target audience.

\section{The influence of the psycho-sociolinguistic criteria on performing the jokes}

The sense of humour and the perception of a joke are strongly influenced by the traditions and culture of the informants involved. At the same time, this perception differs according to the position in the social order, age and gender. Furthermore, we must take into account the fact that a joke can be performed differently by one and the same person, in distinct moments. In a certain situation a humorous structure can stir amusement, whereas in others it may not, depending on the mood of the sender, and on other psychological factors involved in that particular situation. At the same time, the same person can find a joke funny one day and another day he/she may not, depending on their state of mind and on the recent events that happened in their lives. Consequently, in the performance of a humorous structure as well as in its reception, we must take into account the psycho-sociolinguistic aspects.

I consider, therefore, that the way in which each humorous structure is performed depends directly on certain sociolinguistic criteria. In the case of texts (1) and (2) the male speaker, who is a psalm reader, tells a joke about the priest who felt attracted to a woman while he was performing the religious service. Taking into account the criterion of gender affiliation, the psycho-social implications derive from the teller's attitudes: the woman is seen as a temptation, no matter the circumstance (Oh, Maria was nice, no doubt she was nice); the priest is a man, not only a member of the clergy (Pull down your blouse Maria, 'cause your privates are uncovered and I can't say the prayer!); the woman is believed to be a sinner, not the man who is craving (Damn it, priest, if she went all the way with the cantor, wouldn't she go all the way with the priest?). On the other hand, taking into consideration his social status, the first informant chooses to tell two jokes from his professional area, and also ethnic jokes, in which the characters are a Romanian man and a Hungarian man. The fact that the two live in the same community as well as their potential friendship are authentic, if we take into account the fact that the area has a Hungarian population of over $80 \%$. 
The performance of some texts that include elements from the speaker's life leads to the informants' higher emotional involvement as compared to a situation of habitual communication. Therefore, the affective or emotional function of the language is highlighted by the spontaneous expression of emotions and impulses by means of intonations, tone modifications, mimicry, gestures, or even the holler and the interjection (Oh dear, priest, priest do not insert it/'cause her hole is deep!), as in the highly emotionally charged states. This is also the source of the persuasive function of the language, through which the informants intend to convince or even influence the receivers of the message: And he looked at her, because he called her Nasta, Nasta, 'cause she was beautiful or she was very beautiful!

Another aspect, mentioned by Lakoff (1975: 23) is illustrated in the case of the female informant in examples $6,7,8$ as well: women use exaggerated intonation contours in comparison with men. In all the examples performed by informant 3 , we can notice that the variation of the voice pitch is oscillating, the duration is unequal, and the tone is rising. In the case of the lamentation songs, we notice a specific intonation that reveals a few of its main functions, as suggested by Wells (2006). In all the three ritual poems, the expression of emotions and attitudes, as well as the focus on certain pieces of information are evident; these aspects activate two of the most important functions: the attitudinal function and the focusing function (Wells 2006: 6). The emphatic function of intonation can be usually sensed in all the presented texts, when the words (the euphemisms) or the phrases that allude to sensitive topics of an erotic nature are mentioned.

As we can notice in the examples, the intonation system is highly dependent on the dialect or the style, the attitude and the mood of the speakers. Using a proper intonation, a performer can convert a serious text into a humorous one. Moreover, pitch range can create altered voices in quoted speech (Bauman, 1986). For example, when the performer imitates the Hungarian man (see example 3) he uses a special intonation in order to reproduce the Hungarian manner of speaking Romanian: " $<_{\mathrm{IM}}$ IO-aş-am IUbit FEmeia meu asară d"e:: \# >" (I so loved, our woman last night eh...). Moreover, it is known that a Hungarian particularity is the stress on the first syllable of a word, thus the Romanian performer takes it into consideration when he imitates in order to produce humour effect.

Humour appears in that kind of structures in which the intonation is combined with a pitch range and some stressed words or stressed utterances that have double connotation. For instance, in example 8, the intonation is according to the type of text performed (a funeral song), but the words that are stressed allude not to the death theme, but to the erotic one.

Finally, visual cues represent important elements that stir the amusement. In some situations, the performer starts smiling or laughing before the punch line, so he is preparing the audience to react in the same manner. Hence, in all 11 examples the incongruity is constructed not only at the linguistic level, but also through the interaction between the verbal and visual cues. Thus, while performing the funeral song (example 10), the informant mimics the mother's cry and brings the arm to the chest as she has the heart broken, but instead of stirring pity and compassion the gestures produce humorous effect due to the fact that the topic of the text suggests something else.

\section{Conclusion}

By applying the linguistic and non-linguistic theories of humour, the cognitive, aesthetic and motivational potentiality of a comic structure can be determined. Based on our data, it is shown that a humorous effect can be found in any type of text, even if its main content is a tragic one, as in the case of the lamentation song. The success of a humorous structure is 
achieved by overlapping different scripts that have as a final point a surprise which exceeds the receiver's expectations.

At the same time, from all the conditions the humour needs in order to exist I underline those suggested by Veatch (1998). Thus, a humorous structure involves the misleading of the receiver's expectation and, at the same time, the creation of the impression that the depicted fact is acceptable. In other words, humour succeeds when the presented situation is not completely beyond what is expected, but might still exhibit certain irregularities that bring about the receiver's surprise.

An equally important aspect revealed throughout our analysis is the fact that the psychosociolinguistic principles have a very important role in performing humour. Therefore, the criteria of gender and social status explain the motivation to choose a certain humorous structure over another. Furthermore, psycholinguistic concepts highlight the importance of intonation and of imitation when performing a joke. As noticed from the data examined, the intonation and visual cues are most relevant to the production of humour. The intonation, the high or low pitch, the tone and body language not only contextualise the linguistic elements of the text but also contribute to turn the text into a comical one. For Ruiz Gurillo (2012: 5) paralinguistic elements (intonation, body language, smile, laugh, and pause) are very important when they are surrounding verbal jokes because they prepare the receiver to expect something comical.

In conclusion, in this paper I focused on identifying the linguistic and non-linguistic elements used by the speakers of the Upper Valley of the river Mures in order to generate humour, and on how the clash of the contrastive scripts of a text leads to a humorous effect. Performers appear to combine verbal elements with non-linguistic/paralinguistic ones, while the dissociation of the scripts emerging in their texts can be identified not only at the verbal level, but also when the linguistic forms do not correspond to the accompanying nonlinguistic or paralinguistic elements.

Free expression and the sensitive topic approach or the use of vulgar words show that people in the rural communities publicly express themselves without constraints or boundaries. Finally, humour emerges as is grounded not only in the aspirations but also in the limitations of human beings and it is also a mirror of social relations, of people's needs and desires.

\section{Notes}

${ }^{1}$ Both the transcription (dialectal transcription) and the translation of the texts (shouts, lamentation or jokes) are made by the author for the purpose of the present study. The following conventions were used as adapted from Ionescu-Ruxăndoiu (2002).

Uppercase stressed words of utterance

$<$ MARC > stressed parts of utterance

$\mathbf{X}:$ : $\mathbf{x}:$ : prolongation of a sound

(....) comments and contextual information added by the author falling intonation

\# pause

$\downarrow \quad$ ongoing intonation

$\langle$ IM $\rangle \quad$ imitation

$\left.<_{\mathbf{R}}\right\rangle$ fast tempo of the voice

$<\hat{\imath}>\quad$ rising pitch of the voice

$\perp \quad$ false start

$=\quad$ phrase that is continued by other person 
! exclamation

? rising intonation

$<@ \quad$ laughing and speaking at the same time

'Even though in the translation we see the same form, "our women", which is perfectly correct in English, when we refer to feminine noun in Romanian we attach not only grammatical features for plural as in English (our women), but also grammatical feature for gender ("our women" should be translated in Romanian as "femeile noastre"). Using the expression "our women", the Hungarian said "femeile noștri", which is not correct since the word "noștri" ("our") is the proper form for masculine plural and not for feminine plural, that is why the Romanian continually corrected him.

${ }^{3}$ In this case, the expression "my women" ("femeia meu") is used by the Hungarian in an improper way, because he didn't attach the grammatical features for gender which are specific for Romanian, but he combined feminine noun with masculine possessive form (femeia [feminine noun] meu [masculine possessive form] instead of femeia [feminine noun] mea [feminine possessive form]).

\section{References}

Attardo, S. \& Raskin, V. (1991). 'Script theory revis(it)ed: joke similarity and joke representation model'. Humour: International Journal of Humour Research, 4 (3/4), pp. 293-347.

Bauman, R. (1986). Story, Performance, and Event. Cambridge: Cambridge University Press.

Dobreanu D. \& Dobreanu V. (1999). Subcetate Mureș- File de monografie, Cluj- Napoca: Editura Motiv.

Freud, S. (1905 [1974]). Jokes and Their Relation to the Unconscious (Der Witz und seine Beziehung zum Unbewußten). James Strachey (tr.), New York: Penguin.

Gruner, Ch. R. (2000 [1997]). The Game of Humour: A Comprehensive Theory of Why We Laugh. New Brunswick, N.J.: Transaction Publishers.

Hobbes, Th. (1651 [1982]). Leviathan. New York: Penguin.

Ionescu-Ruxăndoiu, L. (coord.) (2002). Interacţiunea Verbală în Limba Română Actuală. Corpus (selectiv). Schiţă de Tipologie. București: Editura Universităţii din Bucureşti.

Kant, I. (1790 [1911]). Critique of Judgment. James Creed Meredith (tr.), Oxford: Clarendon Press.

Koestler, A. (1964). The Act of Creation. New York: Penguin Books.

Ladd, D. R. (1978). 'Stylized intonation'. Language, 54, 517-540.

Lakoff, R. T. (1975). Language and Women's Place. New York: Harper and Row.

Ludovici, A. (1932). The Secret of Laughter. London: Constable.

Martin, R., Puhlik-Doris, P, Larsen, G., Gray, J. \& Weir K. (2003). 'Individual differences in uses of humour and their relation to psychological well-being: Development of the Humour Styles Questionnaire'. Journal of Research in Personality 37 (1), pp. 48-75.

Raskin, V. (1985). Semantic Mechanisms of Humour. Dordrecht: D. Reidel.

Ruiz Gurillo, L. (2012). La Lingüistica del Humor en Español. Madrid: Arco/Libros S.L.

Schopenhauer, A. (1818/1844 [1907]). The World as Will and Idea (Die Welt als Wille und Vorstellung), tr. R. B. Haldane and J. Kemp, $6^{\text {th }}$ ed., London: Routledge \& Kegan Paul.

Suls, J. (1972). 'A two-stage model for the appreciation of jokes and cartoons: An information-processing analysis', in Goldstein, J. \& McGhee P., The Psychology of Humour, New York: Academic Press, pp. 81-99. 
Veatch, T. C (1998) 'A theory of humour'. Humour: International Journal of Humour Research 11 (2), pp. 161-215.

Wells, J. C. (2006). English Intonation. An Introduction. London: Cambridge University Press.

Zafiu, R. (2007). 'Evaluarea umorului verbal', in G. Pană-Dindelegan (coord.): Limba română. Stadiul actual al cercetării, București: Editura Universității din București, pp. 497-505. 